\title{
Hoverfly diversity (Diptera: Syrphidae) of Pyrenean oak woodlands in Central-Western Spain: a preliminary study with conservation outcomes
}

\author{
Á. Gaytán ${ }^{1}$ (D) A. Ricarte ${ }^{2} \cdot$ G. González-Bornay ${ }^{3}$
}

Received: 30 May 2019 / Accepted: 17 December 2019 / Published online: 21 December 2019

(c) The Author(s) 2019

\begin{abstract}
Hoverflies are frequently used as biodiversity indicators and are targets of ecological studies across Europe. How hoverfly diversity responds to ecological variables is essential for species and habitat conservation. The present study is a first attempt to assess the hoverfly diversity of deciduous woodlands of Pyrenean oak (Quercus pyrenaica) in La Vera (Central-Western Spain), a habitat in need of conservation and a region that is poorly known in terms of hoverflies. Hoverflies were sampled with hand net in a mature-woodland site, a young-woodland site, and two close-by grassland sites. A higher number of species and individuals was recorded in woodland sites than in grassland sites, with only two species exclusive to the grasslands and thus, suggesting that woodland sites might be acting as a hoverfly reservoir and source. The proportion of species with phytophagous and saprophagous larvae in woodland sites was higher than outside the woodlands, probably due to a higher availability of resources in woodland sites for phytophagous and saprophagous species. The mature woodland was found to have a higher number of species and individuals than the young woodland, possibly due to the presence of grassy clearings and rotting materials in the trees of the mature woodland. The highest number of species was found in the predatory guild (Syrphinae), and smaller-bodied species within this guild were found to be more frequent in grassland than in woodland sites; possible explanations for this result are discussed. Further investigation is required to confirm and expand the results and conclusions found in this initial study on the hoverfly community of the poorly studied $Q$. pyrenaica woodlands of Central-Western Spain.
\end{abstract}

Keywords Abundance $\cdot$ Bioindicators $\cdot$ Species richness $\cdot$ Functional groups $\cdot$ Hoverflies $\cdot$ Spain $\cdot$ Quercus pyrenaica

\section{Introduction}

Hoverflies are important bioindicators (Sommaggio 1999; Monteil 2010; Speight et al. 2010), with over 970 species present in a wide range of European habitats (Speight 2018). They participate in pollination, herbivory, predation, decomposition and other ecosystem processes. Adults feed on

\section{Á. Gaytán}

alvaro.gaytan@su.se

1 Department of Ecology, Environment and Plant Sciences, University of Stockholm, Stockholm, Sweden

2 CIBIO Institute, University of Alicante, Carretera de San Vicente del Raspeig s/n, San Vicente del Raspeig, 03690 Alicante, Spain

3 Grupo de investigación Forestal, INDEHESA, University of Extremadura, Plasencia, Spain pollen and nectar of Apiaceae, Asteraceae, Ranunculaceae, and Rosaceae, among others (Rotheray and Gilbert 2011). Larvae are trophically diverse (Rotheray 2019) and develop in different microhabitats (Speight 2018). Phytophagous larvae feed on underground and aerial parts of live plants as borers or miners (Stuke 2000; Ricarte et al. 2017). Zoophagous larvae prey on a wide range of insects, both in the undergrowth and in the aerial parts of plants (Rojo et al. 2003; Reemer 2012). Saprophagous larvae are filter-feeders of bacteria and/or detritus found in decaying materials both of animal and vegetal origins (Rotheray 2019); within saprophagous, those larvae depending on dead wood or decaying materials associated with woody parts of trees are saproxylic (Speight 1989; Rotheray et al. 2001).

For using hoverflies as bioindicators of habitat integrity, the hoverfly community composition and the hoverfly diversity responses to ecological variables are essential factors to be understood. Mediterranean woodlands have a 
high hoverfly diversity due to the variety of developmental sites for larvae and flower resources for adults (Ricarte et al. 2011). In saproxylic communities of 'dehesas' (open woodlands of Quercus), hoverfly species composition is not affected by tree density neither by scrub cover (RamírezHernández et al. 2014). In the Western Mediterranean Basin, the deciduous woodlands of Pyrenean oak (Quercus pyrenaica Willd.) are in need of conservation after a long history of human use (Gavilán et al. 2000), which is still more intense in this tree species than in other oaks such as Quercus rotundifolia Lam. (Ramírez-Hernández et al. 2014). Nonetheless, $Q$. pyrenaica woodlands are richer in hoverfly species than other Mediterranean woodlands or habitats (Ricarte and Marcos-García 2008), excepting the saproxylic species that appear to be more diverse in the Quercus rotundifolia 'dehesas' than in the Q. pyrenaica 'dehesas' (Ramírez-Hernández et al. 2014). Woodland sites in grassland-dominated landscapes may act as refuges for hoverflies against harsh environmental conditions of grasslands (Ricarte et al. 2011). However, small grasslands ('grassy clearings') promote hoverfly diversity within woodlands (Gittings et al. 2006; Ricarte et al. 2011). The community of hoverflies (and Diptera in general) in open habitats might consist of a higher number of small-bodied species, in comparison with close habitats (woodlands), but responses of organisms are complex and difficult to generalise at this regard (Chown and Gaston 2010; Klecka et al. 2018).

The ecological characterisation of Mediterranean hoverfly communities is still poor, with few studies dealing with taxonomic and/or functional diversities in relation to ecological variables (Ricarte et al. 2011; Quinto et al. 2014; RamírezHernández et al. 2014). The main aim of the present study is to approach the ecological characterisation (abundance, species richness and functional diversity) of the hoverfly community of a Spanish deciduous forest of Pyrenean oak, in a region (La Vera) where 31 hoverfly species are recorded so far (Gaytán et al. 2016). Hoverfly diversity in the Mediterranean region is influenced by the vegetation type of sites, in such a way that woodland sites are more diverse than grassland sites (Ricarte et al. 2011). The first specific aim (1) of this study is to compare the hoverfly diversity between sites of Pyrenean oak forest and close-by grasslands. A higher diversity of hoverflies is expected in woodland than in grassland sites. Forest traits in the Mediterranean region influence their insect diversity. For example, woodlands with mature trees, i.e. older and bigger in size, usually have a wider range of breeding sites for saproxylic species and then its saproxylic community tends to be more diverse than in woodlands with smaller-size trees (Ramilo et al. 2017). The second specific aim (2) of the present study was to test differences in hoverfly diversity between 'mature' and 'young' woodlands. We expect the mature forests to be more diverse than the young. Finally, habitat type seems to have an effect on the body size of insects, for instance carabid (Coleoptera: Carabidae) body size is significantly greater in English woodlands than in grasslands (Blake et al. 1994). The third specific aim (3) of this paper was to test differences in the body size of the hoverflies found in forests and close-by grasslands by focusing on the hoverfly guild with the highest species richness. Smaller-bodied species are expected in grasslands.

Results expected from this preliminary study are supposed to show tendencies to be tested in future investigations.

\section{Material and methods}

\section{Study area}

The sampling sites were located in Cuacos de Yuste, La Vera region, north of Cáceres province, Extremadura (CentralWestern Spain) (Fig. 1). La Vera has an altitude ranging of 260-2000 m asl, soils are sandy-loam, originated by the granite erosion, and with a pH of 5-6.5 (Gallardo 2015). Climate is temperate continental Mediterranean, with moderate temperatures (average annual temperature: $16{ }^{\circ} \mathrm{C}$ ) (RivasMartínez 1987).

The sampling took place in Pyrenean oak woodlands, as well as in close-by grasslands. Pyrenean oaks occur along South-Western Europe and North-Western Africa, being more abundant in Northern Portugal and North and NorthWestern Spain (Gavilán et al. 2007). An individual Pyrenean oak can reach up to $20 \mathrm{~m}$ high under favourable conditions. Their leaves are deeply lobed and are pubescent on both sides (Devesa 1995).

Hoverflies of four sites (Fig. 2) were surveyed: (1) woodland site $(40.106825,-5.736134), 38$ ha, with young $Q$. pyrenaica trees (trunk diameter $<75 \mathrm{~cm}$ ) and two seasonal brooks; understory vegetation included plants such as Ranunculus arvensis, Calendula arvensis (grasses), Arbutus unedo, Citysus sp., Lavandula stoechas, Rubus spp. (scrubs), and oak seedlings; managed woodland (wood extraction), but, due to the overlap amongst the treetops, the canopy cover was still complete (no sunlight underneath the cover); (2) woodland site $(40.149019,-5.723547), 41$ ha, with mature $Q$. pyrenaica trees (trunk diameter $>75 \mathrm{~cm}$ ), and no water points within it; some grassy clearings present, with a low diversity of plants dominated by Asphodelus albus; unmanaged woodland, canopy cover non-complete $(<100 \%)$ allowing the sunshine in some points; (3) grassland site near the mature woodland $(40.142739,-5.714692)$, consisting of small grasses $(\mathrm{c} .15 \mathrm{~cm})$ and isolated patches of $L$. stoechas and Origanum vulgare; (4) grassland site near the young woodland (40.105266, - 5.750985), with small grasses $(<15 \mathrm{~cm})$ and scattered individuals of Citysus spp.. The extension of (3) and (4) was 36 ha altogether. 


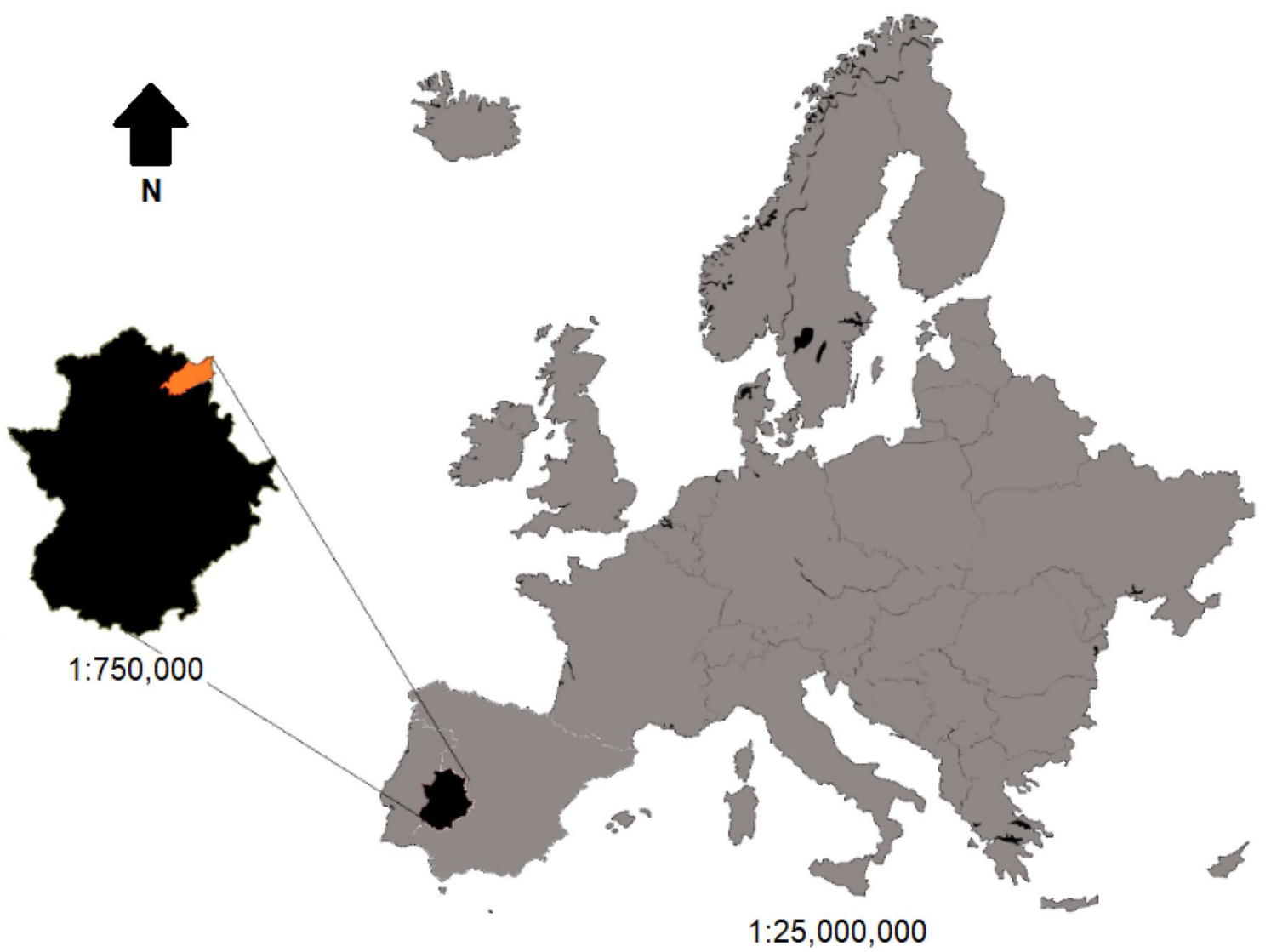

Fig. 1 Location of the study area: La Vera region (in orange), Extremadura (in black), Central-Western Spain, Europe

\section{Hoverfly sampling}

Adult hoverflies were sampled with an entomological net in the four selected sites. A zig-zag transept was followed at each site, with a sampling effort of $25 \mathrm{~min}$, in order to cover the maximum extension. During the transept, the collector paid special attention to places with higher attraction potential for hoverflies: flower patches (mainly of Asteraceae plants), streams, water pools, and ponds. All four sampling sites were visited every fortnight from April 2014 to June 2015 , but excluding the period from the second half of September to the end of April due to low temperature and high humidity. In total, 52 surveys took place. Rainy and windy days were avoided due to the absence or scarcity of hoverflies in flight. All the required permits for collecting insects were made available by the autonomous government of Extremadura, 'Junta de Extremadura' (Reference code: "EMCF/jca").

\section{Hoverfly identification}

Most data used for the present ecological study come from the identifications in Gaytán et al. (2016). However, we give here additional details about the specimen preparation and identification in the lab of these and other specimens.

Hoverflies were identified in the field and released, but those that required identification with microscope were killed with ethyl acetate gases $\left(\mathrm{C}_{4} \mathrm{H}_{8} \mathrm{O}_{2}\right)$ (Márquez 2005) and then transported to the lab to be mounted and labelled adequately. Specimens were identified with Ball et al. (2013), Speight and Sarthou (2014), Stubbs and Falk (2002), Van Veen (2010), Violovitsh (1974), and Marcos-García et al. (2000). For some specimens, male genitalia examination was required. Genitalia were dissected with pins and forceps from softened specimens after $24-48 \mathrm{~h}$ in a damp bell, then boiled individually in glass tubes with potassium hydroxide $(\mathrm{KOH})$ diluted in water for $5 \mathrm{~min}$, immersed in acetic acid $\left(\mathrm{C}_{2} \mathrm{H}_{4} \mathrm{O}_{2}\right)$ to neutralize the residual $\mathrm{KOH}$, and finally placed in ethanol $\left(\mathrm{C}_{2} \mathrm{H}_{6} \mathrm{O}\right)$ to remove the acid excess. Genitalia were stored in plastic micro-vials with glycerine.

\section{Statistical analyses}

To test differences in the abundance and richness of hoverflies between the woodland sites and the sites outside woodlands, we run a generalized linear model (GLMs) using the R-package 'stats' (R Development Core Team 2016). We 
Fig. 2 The four sampling sites studied in La Vera (Central-

Western Spain) where hoverflies were surveyed. In red, woodland sites; in green, close-by grassland sites

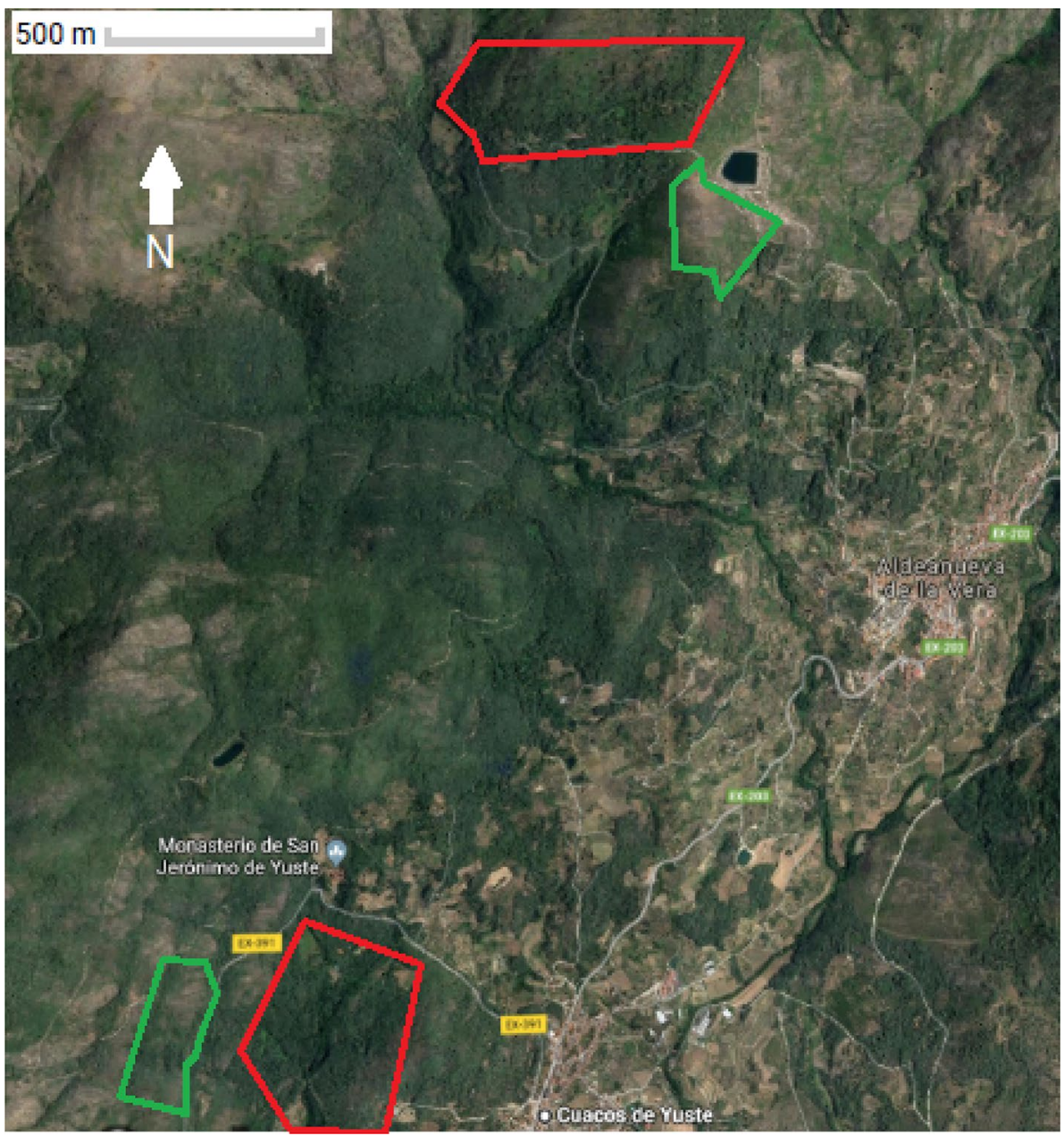

modelled the 'number of individuals' (following a Poisson distribution) of each species as a function of the 'species', the 'site' (inside or outside the deciduous woodland) and the interaction among both predictors. For testing differences in the hoverfly functional groups between the woodland sites and the sites outside woodlands, we run three GLMs (following a binomial distribution) taking 'phytophagous', 'predatory' and 'saprophagous' species as response variable for each of the three models respectively; and using the site as categorical variable to distinguish observations within woodland sites and with close-by grassland sites as predictor. Hoverflies were categorised in different functional groups according to Speight (2018).

To test differences in the abundance and species richness of hoverflies and the differences in the hoverfly functional groups between mature and young woodland sites, we run the same four GLMs previously described but adapting the categories of the variable 'site' as: mature or young woodland.

Since most of the collected species were predatory (18 out of $23 \mathrm{~s}$ ), we choose this functional group to analyse the differences in the species body size between the hoverfly diversity found inside the woodland sites and in the sites outside woodlands. Species body size is based on the adult body length provided in the 'All other sheets' spreadsheet of Speight et al. (2016) for all European species of hoverflies. In Speight et al. (2016), adult body length is measured from the anterior extremity of the head (excluding the antennae) to the posterior extremity of the abdomen, given to the nearest $0.5 \mathrm{~mm}$. To test differences in species size between woodland sites and with the grassland sites, we run a GLM (following a Poisson distribution) using the 'body length' as response variable and the 'site' (inside or outside the deciduous woodland) as predictor.

For any of the above mentioned analyses, saprophagous species were not split into 'saproxylic' and 'non-saproxylic' due to the low number of species recorded in this functional group (four out of 23 , with only one saproxylic species, see Table 1). 
Table 1 List of hoverflies collected in two woodland sites and two close-by grassland sites in La Vera region, CentralWestern Spain

\begin{tabular}{|c|c|c|c|c|c|}
\hline Species & Site (1) & Site (2) & Site (3) & Site (4) & $\begin{array}{l}\text { Func- } \\
\text { tional } \\
\text { group }\end{array}$ \\
\hline Brachypalpus valgus & 0 & 5 & 0 & 0 & $\mathrm{Sp}^{*}$ \\
\hline Cheilosia scutellata & 2 & 16 & 1 & 0 & $\mathrm{Ph}$ \\
\hline Chrysotoxum octomaculatum & 6 & 4 & 0 & 0 & $\operatorname{Pr}$ \\
\hline Dasysyrphus albostriatus & 0 & 1 & 0 & 0 & $\operatorname{Pr}$ \\
\hline Didea fasciata & 0 & 1 & 0 & 0 & $\operatorname{Pr}$ \\
\hline Episyrphus balteatus & 35 & 63 & 0 & 0 & $\operatorname{Pr}$ \\
\hline Eristalinus taeniops & 0 & 1 & 0 & 0 & $\mathrm{Sp}$ \\
\hline Eristalis tenax & 9 & 10 & 3 & 0 & $\mathrm{Sp}$ \\
\hline Eupeodes corollae & 1 & 1 & 1 & 2 & $\operatorname{Pr}$ \\
\hline Eupeodes lucasi & 0 & 1 & 0 & 0 & $\operatorname{Pr}$ \\
\hline Eupeodes luniger & 0 & 0 & 1 & 0 & $\operatorname{Pr}$ \\
\hline Melanostoma mellinum & 0 & 0 & 2 & 0 & $\operatorname{Pr}$ \\
\hline Melanostoma scalare & 3 & 2 & 3 & 6 & $\operatorname{Pr}$ \\
\hline Meliscaeva auricollis & 2 & 3 & 13 & 12 & $\operatorname{Pr}$ \\
\hline Paragus haemorrhous & 2 & 0 & 0 & 5 & $\operatorname{Pr}$ \\
\hline Platycheirus albimanus & 0 & 1 & 2 & 0 & $\operatorname{Pr}$ \\
\hline Scaeva pyrastri & 0 & 1 & 0 & 0 & $\operatorname{Pr}$ \\
\hline Sphaerophoria scripta & 4 & 0 & 21 & 18 & $\operatorname{Pr}$ \\
\hline Syritta pipiens & 1 & 2 & 4 & 0 & $\mathrm{Sp}$ \\
\hline Syrphus ribesii & 0 & 5 & 2 & 6 & $\operatorname{Pr}$ \\
\hline Syrphus vitripennis & 0 & 3 & 0 & 0 & $\operatorname{Pr}$ \\
\hline Volucella inanis & 1 & 7 & 0 & 0 & $\operatorname{Pr}$ \\
\hline Xanthandrus comtus & 1 & 0 & 0 & 0 & $\operatorname{Pr}$ \\
\hline Individuals & 67 & 127 & 53 & 49 & \\
\hline Species & 12 & 18 & 11 & 6 & \\
\hline
\end{tabular}

Sampling sites: (1) young woodland site; (2) mature woodland site; (3) grassland site near mature woodland; (4) grassland site near young woodland. Legend of the 'Functional group': $\mathrm{Ph}$, species with phytophagous larva; Pr, species with predatory larva; Sp, species with saprophagous larva; Sp*, species with saproxylic larva. Most material was included in Gaytán et al. (2016)

\section{Results}

\section{Hoverfly diversity}

Hoverflies were surveyed in two woodland sites ('mature' and 'young') and two grassland sites next to the woodlands. A total of 296 specimens representing 23 species and 19 genera were collected, 21 species in the woodland sites and 12 in the grassland sites. Seven species were exclusive to the mature woodland site, only one to the young woodland, and two to the close-by grasslands. All three functional groups were represented at each woodland site, as well as in the close-by grasslands, with one species with phytophagous larva, four with saprophagous larvae (only one saproxylic: Brachypalpus valgus), and 18 with predatory larvae. The species with the highest number of records was Episyrphus balteatus (predatory), with 98 specimens. Seven species (all except one predatory) were singletons (Table 1).

\section{Woodland sites vs. close-by grassland sites}

The abundance and species richness was significantly higher in the woodland sites (194 individuals of 21 species) than in grassland sites (102 individuals of 12 species) $(\mathrm{F}=7.57$, $\mathrm{df}=1, \mathrm{p}=0.006$; Tables 1 and 2). The proportion of phytophagous species in woodland sites was 5\% (18 specimens) while in grassland sites these species were almost absent ( 1 specimen) $(\mathrm{F}=7.814, \mathrm{df}=1, \mathrm{p}=0.006$; Fig. 3$)$. In addition, the proportion of saprophagous species was significantly higher in grassland sites $(\mathrm{F}=11.654, \mathrm{df}=1, \mathrm{p}<0.001$; Fig. 3). Finally, the proportion of predatory species in the woodland and the grassland sites was similar $(76.19 \%$ and $75.00 \%$, respectively) $(\mathrm{F}=3.696, \mathrm{df}=1, \mathrm{p}=0.060$; Fig. 3).

\section{Mature woodland site vs. young woodland site}

The abundance and species richness of hoverflies was significantly higher in the mature woodland site (127 individuals 
Table 2 The effects of the species composition and habitat type (model 1: inside or outside the woodland; model 2: 'young' or 'mature' woodlands) on the hoverfly abundance

\begin{tabular}{llrrr}
\hline Response variable & Predictors & $\chi^{2}$ & df & p \\
\hline $\begin{array}{l}\text { Number of individuals of each species } \\
\text { (model 1) }\end{array}$ & Species & 479.00 & 22 & $<\mathbf{0 . 0 0 1}$ \\
& Site (inside or outside) & 7.57 & 1 & $\mathbf{0 . 0 0 6}$ \\
& Interaction & 75.32 & 9 & $<\mathbf{0 . 0 0 1}$ \\
& (Species: site) & & & \\
Number of individuals of each species & Species & 342.40 & 20 & $<\mathbf{0 . 0 0 1}$ \\
(model 2) & $\begin{array}{l}\text { Woodland } \\
\text { ('young' or 'mature') }\end{array}$ & 13.91 & 1 & $<\mathbf{0 . 0 0 1}$ \\
& Interaction & 12.86 & 8 & 0.117 \\
& (Species: woodland) & & & \\
\hline
\end{tabular}

Significant $\mathrm{p}$-values $(\mathrm{p}<0.05)$ are shown in bold of 20 species) than in the young woodland site (67 individuals of 12 species $)(F=13.91, \mathrm{df}=1, \mathrm{p}<0.001$; Tables 1 and 2). The proportion of phytophagous species was higher than $8.3 \%$ in the mature woodland, while the proportion of phytophagous species was lower than $5.6 \%$ in the young woodland site $(\mathrm{F}=4.887, \mathrm{df}=1, \mathrm{p}=0.028$; Fig. 3$)$. We did not find statistically significant differences in the proportion of predatory and saprophagous species between the mature and the young woodland site $(\mathrm{F}=1.903, \mathrm{df}=1, \mathrm{p}=0.169$ and $\mathrm{F}=0.020, \mathrm{df}=1, \mathrm{p}=0.888$; Fig. 3).

\section{Species body size vs. habitat type}

The guild of hoverflies with predatory larvae was the richest in species. Thus, this guild was considered to test differences in the species body size according to habitat type (woodland or grassland). With an average of $12 \mathrm{~mm}$, the body size of predatory species collected in the woodland sites was significantly higher than that of the predatory species found outside $(\mathrm{F}=72.553$, df $=1, \mathrm{p}<0.001$; Fig. 4). We found a range of body sizes within woodland sites from 4 to $18 \mathrm{~mm}$, while species found outside were up to $11 \mathrm{~mm}$ in body size (average $=10 \mathrm{~mm}$ ) (Fig. 4).

\section{Discussion}

\section{Hoverfly diversity}

In the two studied sites of Pyrenean oak, 21 hoverfly species were collected after 7.5 months of fortnight samplings with hand net. This species number contrasts the 60 species collected in the Pyrenean oak woodlands in Cabañeros national park (Ricarte and Marcos-García 2008), a protected area of Mediterranean forest just over $170 \mathrm{~km}$ from La Vera. In Cabañeros, two woodland sites of Pyrenean oak were also studied, one of which was a mix of $Q$. pyrenaica, Quercus faginea and Fraxinus angustifolia. The difference in the number of collected species is given by (1) a longer period of hand net sampling (13 months vs. 7.5 months), (2) a higher collecting effort with hand net ( $2 \mathrm{~h}$ per survey/site vs. $25 \mathrm{~min}$ ), and (3) the use of an additional sampling technique during an entire year (Malaise trap vs. hand net only) in Cabañeros (Ricarte and Marcos-García 2008; Ricarte et al. 2011). Nonetheless, the list of species collected in La Vera woodlands of Pyrenean oak is not unimportant, including eight species absent from the Cabañeros Q. pyreniaca woodlands (Ricarte and Marcos-García 2008), and four species that were first catalogued for the autonomous community of Extremadura in Gaytán et al. (2016). Future studies will contribute to complete the list of hoverfly species from the Pyrenean oak woodlands in La Vera region.

The Species Selection Tool of Monteil (2010) predicts 58 hoverfly species for the general habitat category ' 1127 : $Q$. pyrenaica forest' without supplementary habitats such as grassy clearings or brooks. Ten of the 21 species collected in the $Q$. pyrenaica woodlands of La Vera are absent from the above mentioned prediction, i.e. not expected to be found in this woodland type; these species are D. fasciata, E. taeniops, E. tenax, E. corollae, M. scalare, M. auricollis, S. pyrastri, S. scripta, S. pipiens, and S. vitripennis, all recorded fro Spain. However, some of these species can be present in $Q$. pyrenaica woodlands, if supplementary habitats are included. For example, E. corollae, M. scalare, $S$. pyrastri, and $S$. scripta are predicted for the $Q$. pyrenaica woodlands, if 'grassy clearings' and 'seasonal brooks' are selected as supplementary habitats (Monteil et al. 2007), what fits to the features of the two studied woodland sites: young woodland site with two seasonal brooks and mature woodland site with grassy clearings (see "Material and methods"). Nonetheless, D. fasciata and E. taeniops are predicted by Monteil (2010) under any circumstance. So, on the one hand the predictive potential of Monteil (2010) is confirmed in the present study, and on the other hand the results obtained may contribute to complete the Syrph the Net database (Speight et al. 2010) and then optimise the use of Monteil (2010).

Samplings in the grassland sites fitted a lower number of hoverfly species than in the woodlands, with two species exclusive to the grassland sites: E. luniger and $M$. 
Fig. 3 Number of hoverflies with phytophagous larvae (grey), predatory larvae (black) and saprophagous larvae (white) found inside/outside the woodland sites (top graphic) and in young/mature woodland sites (bottom graphic) in La Vera region, Central-Western Spain. 'Outside' sampling took place in two grassland sites near the woodland sites
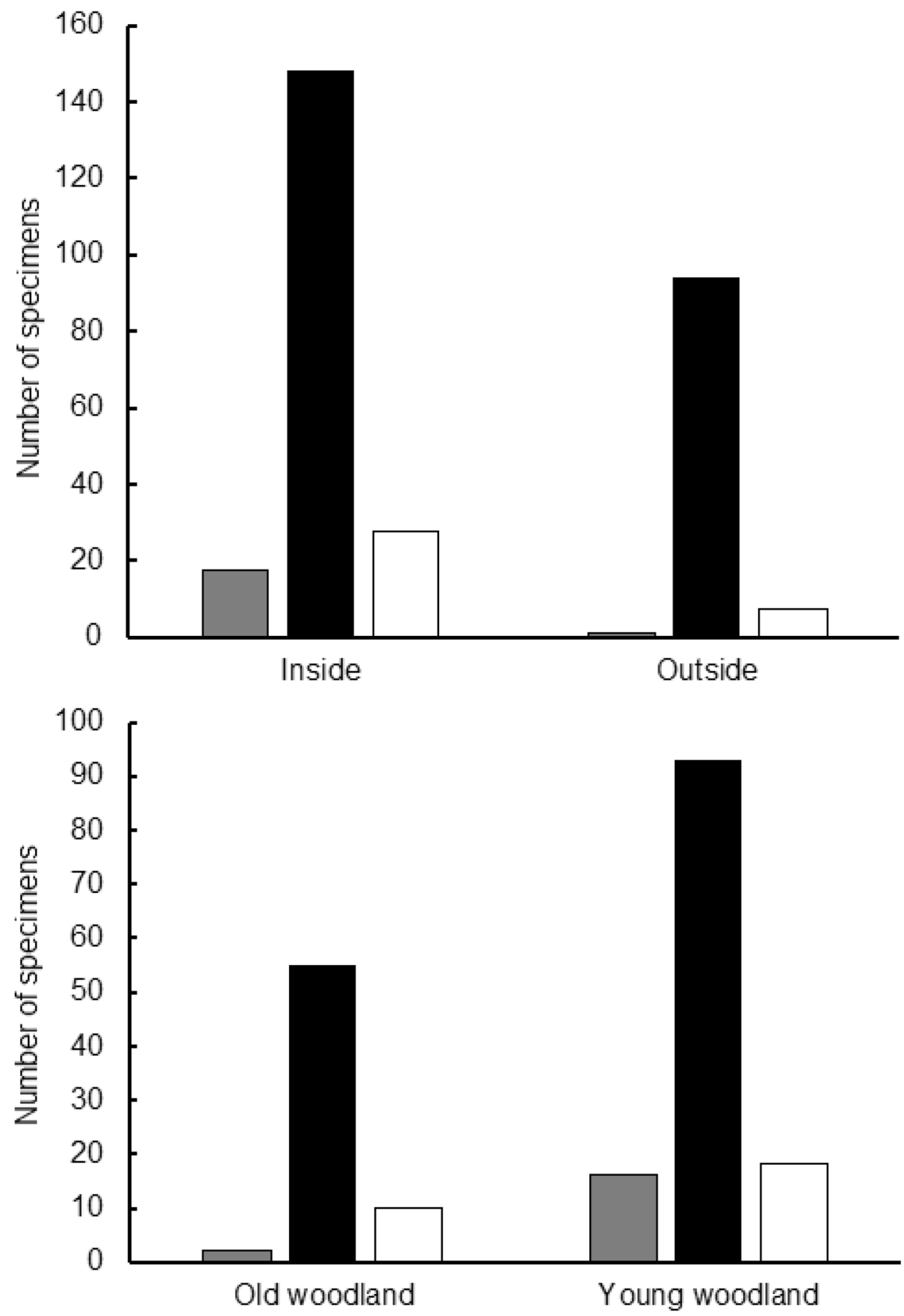

mellinum. The preferred environment of the anthropophilic E. luniger adults is open, including grasslands and woodland clearings (Speight 2018). This is actually one of the species predicted for $Q$. pyrenaica woodlands in Monteil (2010), even if supplementary habitats are excluded from the prediction (Monteil et al. 2007). However, this species has not been collected in the woodland clearings of our sites. Results are not conclusive at this regard, since all collected Eupeodes hoverflies were represented only by one specimen each, and part of these species abundance could have been overlooked during the sampling due to their fast flight (see Speight 2018 for E. luniger). The occurrence of $M$. mellinum exclusively in the grasslands appears to be more consistent with the available literature, since it is also typically found in open environment (Speight 2018), and is predicted for $Q$. pyrenaica woodlands, only if grassy clearings are included as supplementary habitats in the prediction (Monteil et al. 2007; Monteil 


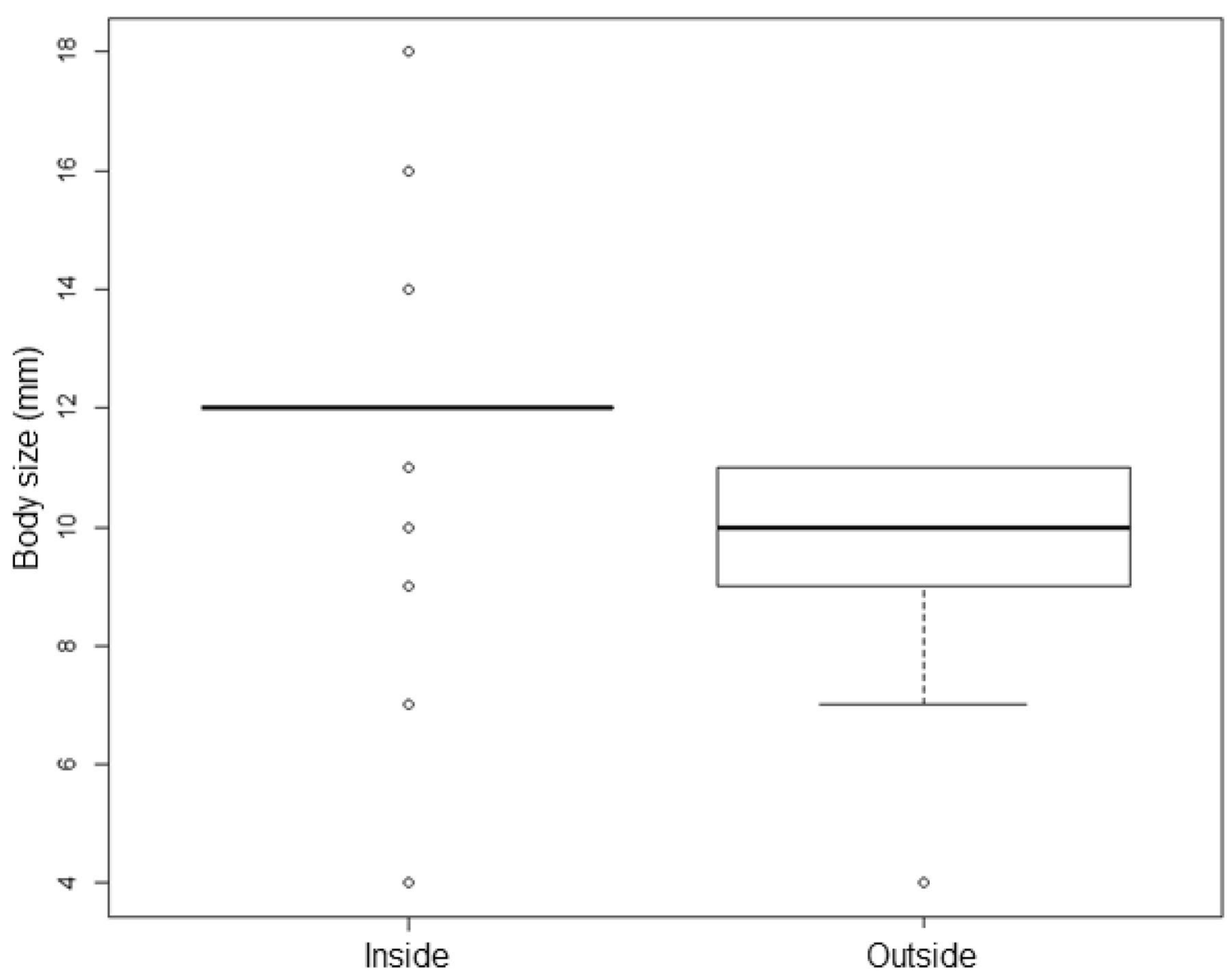

Fig. 4 Body size range of the hoverfly guild dominant in the sampling (predatory species) inside/outside woodland sites in La Vera region, Central-Western Spain. 'Outside' sampling took place in two grassland sites near the woodland sites

2010). In conclusion, the finding of E. luniger and M. mellinum exclusively in the grassland sites is in accordance with our general knowledge on these species preferences (Speight 2018).

Regarding woodland sites, the low number of saproxylic species found (only B. valgus) is remarkable. For example, in the Cabañeros $Q$. pyrenaica woodlands 12 saproxylic species were collected (Ricarte and Marcos-García 2008). In Spain, 68 saproxylic species of hoverflies are recorded, meaning that Cabañeros $Q$. pyrenaica woodlands accommodate around $18 \%$ of the Spanish species (Speight 2018). In Cabañeros, four different woodland types were studied and those of $Q$. pyrenaica had the lowest number of saproxylic species recorded (Ricarte and Marcos-García 2008). In addition, $B$. valgus is a saproxylic species shared by different types of Mediterranean woodlands, including $F$. angustifolia and Quercus suber woodlands (Ricarte and Marcos-García 2008). The reason why $Q$. pyrenaica woodlands appear to have in Spain a low diversity of saproxylic hoverflies might be related to a more intense management of this tree species than in others during history (Gavilán et al. 2000).

\section{Woodland sites vs. close-by grassland sites}

The studied woodland sites of $Q$. pyrenaica had a higher species richness than the grassland sites outside. This result matches those found by Ricarte et al. (2011) in Cabañeros, where Mediterranean woodlands, especially those in grassland-dominated landscapes appear to act as refuges for hoverflies against wind or extreme temperatures. In addition, supplementary habitats such as the grassy clearings occurring in the studied mature-woodland sites promote hoverfly diversity (Gittings et al. 2006; Ricarte et al. 2011) and may justify the higher species richness reported in woodland sites than in grassland sites in La Vera. Species richness and abundance are related variables in other insect groups (Price et al. 1995; Wickramasinghe et al. 2004; Okrikata and Yusuf 2016), and this tendency seems to be obvious also in this study results, because a higher species richness in woodland sites than in grassland sites is accompanied by a higher hoverfly abundance (Table 1 ).

The woodland sites had a higher abundance of phytophagous species (only Cheilosia scutellata represented), while 
the mature woodland site had more collected specimens than the young woodland site. These records are in accordance with $C$. scutellata biology, since its larva feeds on large fungi associated with woodlands (Dely-Drascovits 1972), and then woodlands are the preferred environment for adults (Speight 2018). The richness of saprophagous hoverflies was higher in woodland sites than in grassland sites. The two saprophagous species found in the grasslands (E. tenax and S. pipiens) are highly anthropophilic and generalistic, with larvae developing in a wide range of wet microhabitats from small ponds to fresh dung (Speight 2018). Any of these microhabitats might be present in the studied grasslands or close-by. Regarding the hoverflies with predatory larvae, these had a higher species richness and total abundance in woodland sites than in grassland sites, coinciding with the results found by Ricarte (2008) in the Mediterranean habitats of Cabañeros. While the presence of phytophagous and saprophagous species is limited by the availability of feeding resources and humidity, predatory species can find feeding resources (other insects, mainly aphids) in a wider range of ecosystems and are less dependent on habitat conditions than phytophagous and saprophagous species (Bankowska 1980). Woodlands of Mediterranean ecosystems are environmentally complex having supplementary habitats such as grassy clearings that sustain prey populations for a wider and more abundant community of predatory hoverflies (Ricarte 2008).

\section{Mature woodland site vs. young woodland site}

The higher abundance and species richness of hoverflies in the mature woodland than in the young woodland suggest that the mature woodland provides a wider range of resources for a more diverse hoverfly community. On the one hand, the finding of the saproxylic B. valgus in the mature woodland is related to the fact that mature trees have more rot holes and fissures than younger trees; rot holes and fissures are microhabitats for $B$. valgus larvae (Dušek and Láska 1988, Sánchez Galván et al. 2014). On the other hand, predatory species such as E. lucasi and S. vitripennis prefer woodlands against other habitat types (Speight 2018). The fact that the studied young woodland was under management conditions (see "Material and methods") was likely to impact its habitat integrity, and this might be why hoverfly species preferring woodlands are better represented in the studied unmanaged mature woodland. The specific features of the studied young woodland such as the absence of grassy clearings is likely to be limiting the richness and abundance of hoverfly species in our samplings (Gittings et al. 2006; Ricarte et al. 2011). The finding of X. comtus in the young woodland, but not in the mature woodland is in accordance with this species biology, since adults of this species are frequent in habitats where there are young trees (Speight 2018).

\section{Species body size vs. habitat type}

Observing the body size of the major functional group which was the predatory species (Syrphinae), we noticed that only smaller-bodied species were found outside woodland sites (e.g. M. auricollis and S. scripta), while a wider (and higher) range of body sizes was found amongst the species recorded within woodlands (e.g. V. inanis) (Table 1). This positive tendency of small-bodied species towards open habitats is in accordance with the results found in studies focused on other insect groups (Blake et al. 1994) and might be due to a better adaptation of small-bodied species to the high temperature of open habitats (Chown and Gaston 2010), and/or these small-bodied species using open habitats to go more unnoticed by their natural enemies (Bain et al. 2007). Klecka et al. (2018) showed that flower visitation increased with inflorescence size in small-bodied species of hoverflies. In the grassland sites studied here, plants with bigger inflorescences than those in woodland sites were present (e.g. Bellis sylverstris, Glebionis segetum or Matricaria chamomilla), and they were likely to attract small-bodied species of hoverflies coming from other close-by habitats as tourist species. Finally, the smaller body size of species in grasslands than in woodlands can be an effect of the functional group selected to test differences at this regard. Predatory species belong to a hoverfly subfamily (Syrphinae) that appear to be less specialised in terms of flower visitation than other hoverfly subfamilies (Klecka et al. 2018). Predatory species could be then more likely to be found in habitats with, a priori, less specialised conditions such as grasslands. Our results suggest that further studies with the entire hoverfly community of habitats should be undertaken in the Mediterranean region to better understand the effect of habitat type in the species body size of hoverflies.

\section{Conclusions $^{1}$}

- Mediterranean woodlands of Pyrenean oak seem to have a higher hoverfly diversity than grasslands, with woodlands possibly acting as hoverfly shelters and sources for close-by habitats.

- Supplementary habitats within Pyrenean oak woodlands (e.g. grassy clearings, brooks) are likely to promote hoverfly diversity.

- Mature woodlands of Pyrenean oak with grassy clearings provide resources for a wider hoverfly community than young woodlands without grassy clearings.

\footnotetext{
1 All conclusions to be understood in the framework of Pyrenean oak woodlands and grasslands of La Vera region (Central-Western Spain).
} 
- Hoverfly diversity of Pyrenean oak woodlands consists of species with a wider range of body sizes, while close-by grasslands have smaller-bodied species possibly originating in the woodlands and doing incursions in the grasslands to feed on larger-inflorescence plants.

- Obtained results, although limited by the number of surveyed sites and the sampling effort show important consistencies with the known biology and ecology of collected hoverfly species, indicating that these preliminary findings represent real tendencies in the studied habitats types.

Acknowledgements Open access funding provided by Stockholm University. We thank to the 'Vicerrectorado de Investigación y Transferencia de Conocimiento' for funding Antonio Ricarte's position (Ref. UATAL05) at the University of Alicante.

\section{Compliance with ethical standards}

Conflict of interest The authors declare that they have no conflict of interest.

Open Access This article is licensed under a Creative Commons Attribution 4.0 International License, which permits use, sharing, adaptation, distribution and reproduction in any medium or format, as long as you give appropriate credit to the original author(s) and the source, provide a link to the Creative Commons licence, and indicate if changes were made. The images or other third party material in this article are included in the article's Creative Commons licence, unless indicated otherwise in a credit line to the material. If material is not included in the article's Creative Commons licence and your intended use is not permitted by statutory regulation or exceeds the permitted use, you will need to obtain permission directly from the copyright holder. To view a copy of this licence, visit http://creativecommons.org/licenses/by/4.0/.

\section{References}

Bain RS, Rashed A, Cowper VJ, Gilbert FS, Sherratt TN (2007) The key mimetic features of hoverflies through avian eyes. Proc Biol Sci. 274:1949-1954

Ball S, Ball SG, Morris R (2013) Britain's hoverflies. Princeton University Press, Princeton

Bankowska R (1980) Fly communities of the family Syrphidae in natural and anthropogenic habitats of Poland. Memorab Zool 33:3-93

Blake S, Foster GN, Eyre MD, Luff ML (1994) Effects of habitat type and grassland management practices on the body size distribution of carabid beetles. Pedobiologia 38:502-512

Chown SL, Gaston KJ (2010) Body size variation in insects: a macroecological perspective. Biol Rev. 85:139-169

Dely-Drascovits A (1972) Systematische und Okologische Untersuchungen an den in Ungaren als Schadlinge der Hutpilze auftretenden Fliegen I. Limoniidae, Syrphidae, Platypezidae, Chloropidae (Dipt.). Acta Zool Hung 18:7-21

Devesa JA (1995) Vegetación y flora de Extremadura. Universitas Editorial, Cordoba

Dušek J, Láska P (1988) Saprophage Larven von Ferdinandea cuprea und Brachypalpus valgus (Diptera, Syrphidae). Acta Entomol Bohemoslov 85:307-312
Gallardo JF (2015) The soils of Spain. World soils a book series. Springer, Basel

Gavilán, R., Escudero, A., Rubio, A. (2000): Effects of disturbance on floristic patterns of Quercus pyrenaica forest in central Spain. In: Proceedings of IAVS Symposium: 226Đ229

Gavilán R, Mata DS, Vilches B, Entrocassi G (2007) Modelling current distribution of Spanish Quercus pyrenaica forests using climatic parameters. Phytocoenologia. 37:3-4

Gaytán A, González-Bornay G, Ricarte A (2016) A contribution to knowledge of the hoverflies (Diptera, Syrphidae) of Caceres province. Spain. Bol Asoc Esp Entomol. 20:207-212

Gittings T, O'Halloran J, Kelly T, Giller PS (2006) The contribution of open spaces to the maintenance of hoverfly (Diptera, Syrphidae) biodiversity in Irish plantation forests. For Ecol Manag. 237:290-300

Klecka J, Hadrava J, Biella P, Akter A (2018) Flower visitation by hoverflies (Diptera: Syrphidae) in a temperate plant-pollinator network. PeerJ 6:e6025

Marcos-García MA, Mazánek L, Láska P, Bičik V, Rojo S (2000) Description of the male of Eupeodes lucasi (Marcos-Garcia \& Láska, 1983) and biological data on the species (Diptera, Syrphidae). Volucella. 5:129-138

Márquez J (2005) Técnicas de colecta y preservación de insectos. Boletín Sociedad Entomológica Aragonesa. 37:385-408

Monteil C (2010) A species selection tool for the "Syrph the Net" database. In: Speight, MCD, Castella E, Sarthou JP, Monteil C (eds). Syrph the net on CD, Issue 7. The database of European Syrphidae. Syrph the Net Publications, Dublin

Monteil, C, Speight, M.C.D., Sommaggio, D., and Sarthou, J.P. (2007). Species selection tool for the StN database, 2008. In: Speight, M.C.D., Castella, E., Sarthou, J.-P., Monteil, C. (eds.) Syrph the net, the database of European Syrphidae, vol 58, 32 pp. Syrph the Net publications, Dublin

Okrikata E, Yusuf OA (2016) Diversity and abundance of insects in Wukari, Taraba State. Nigeria. Int Biol Biomed J. 2:156-166

Price PW, Diniz IR, Morais HC, Marques ESA (1995) The abundance of insect herbivore species in the tropics: the high local richness of rare species. Biotropica 27:468-478

Quinto J, Micó E, Marcos-García MA, Martínez-Falcón AP, Galante E (2014) Influence of tree hollow microenvironmental variables on saproxylic guild diversity in Iberian Mediterranean woodland. J Insect Conserv. 18:981-992

R Development Core Team (2016) R: a language and environment for statistical computing. R foundation for Statistical computing, Vienna. https://www.r-project.org

Ramilo P, Guerrero JR, Micó E, Galante E (2017) Volatile organic compounds emitted by Quercus pyrenaica Willd., and its relationship with saproxylic beetle assemblages. Arthopod-Plant Interactions 11:221-234

Ramírez-Hernández A, Micó E, Marcos-García MA, Brustel H, Galante E (2014) The "dehesa", a key ecosystem in maintaining the diversity of Mediterranean saproxylic insects (Coleoptera and Diptera: Syrphidae). Biodivers Conserv 23(8):2069-2086

Reemer M (2012) Unravelling a hotchpotch: phylogeny and classification of the Microdontinae (Diptera: Syrphidae). Doctoral thesis, Leiden University

Ricarte A (2008) Biodiversidad de sírfidos (Diptera: Syrphidae) y conservación de los hábitats en el Parque Nacional de Cabañeros, España. Tesis doctorales de la Universidad de Alicante

Ricarte A, Marcos-García MA (2008) Los sírfidos (Diptera: Syrphidae) del Parque Nacional de Cabañeros (España): una herramienta para la gestión. Bol Asoc Esp Entomol. 32:19-32

Ricarte A, Marcos-García MA, Moreno CE (2011) Assessing the effects of vegetation type on hoverfly (Diptera: Syrphidae) diversity in a Mediterranean landscape: implications for conservation. J Insect Conserv. 15:865-877 
Ricarte A, Souba-Dols GJ, Hauser M, Marcos-García MA (2017) A review of the early stages and host plants of the genera Eumerus and Merodon (Diptera: Syrphidae), with new data on four species. PLoS ONE 12:e0189852

Rivas-Martínez S (1987) Memoria del mapa de series de vegetación de España 1:400,000. ICONA Ministerio de Agricultura, Pesca y Alimentación, Madrid

Rojo S, Gilbert F, Marcos-García MA, Nieto JM, Mier MP (2003) A world review of predatory hoverflies (Diptera, Syrphidae: Syrphinae) and their prey. CIBIO Ediciones, Alicante

Rotheray GE (2019) Ecomorphology of cyclorrhaphan larvae (Diptera). Zoological monographs 4. Springer, Heidelberg

Rotheray GE, Gilbert FS (2011) The natural history of hoverflies. Forrest Text, Cardigan

Rotheray GE, Hancock G, Hewitt S, Horsfield D, MacGowman I (2001) The biodiversity and conservation of saproxylic Dipetra in Scotland. J Insect Conserv. 5:77-85

Sánchez Galván IR, Quinto J, Micó E, Galante E, Marcos-García M-A (2014) Facilitation among saproxylic insects inhabiting tree hollows in a mediterranean forest: the case of cetonids (Coleoptera: Cetoniidae) and Syrphids (Diptera: Syrphidae). Environ Entomol 43(2):336-343

Sommaggio D (1999) Syrphidae: can they be used as environmental bioindicators? Agric Ecosyst Environ. 74:343-356

Speight, M.C.D. (1989) Saproxylic invertebrates and their conservation. Nature and Environment Series, No.42. Strasbourg: Council of Europe.

Speight MCD (2018) Species accounts of European Syrphidae, 2018. Syrph the Net, the database of European Syrphidae (Diptera). Syrph the Net Publications, Dublin

Speight MCD, Sarthou JP (2014) StN keys for the identification of the European species of various genera of Syrphidae (Diptera):
Syrph the Net, the database of European Syrphidae. Syrph the Net Publications, Dublin

Speight MCD, Monteil C, Castella E, Sarthou JP (2010) StN 2010. In: Speight MCD, Castella E, Sarthou JP, Monteil C (eds). Syrph the Net on CD, Issue 7. The database of European Syrphidae. Syrph the Net Publications, Dublin

Speight MCD, Castella E, Sarthou JP (2016) StN 2016. In: Syrph the Net on CD, Issue 11. Speight MCD, Castella E, Sarthou JP, Vanappelghem C (Eds.) ISSN 1649-1917. Syrph the Net Publications, Dublin

Stubbs AE, Falk SJ (2002) British hoverflies. British Entomological and Natural History Society, Wokingham

Stuke JH (2000) Phylogenetische Rekonstruktion der Verwandtschaftsbeziehungen innerhalb der Gattung Cheilosia Meigen, 1822 anhand der Larvenstadien (Diptera: Syrphidae). Stud Dipterol Suppl. 8:1-118

Van Veen MP (2010) Hoverflies of Northwest Europe. Identification key to the Syrphidae. KNNV Publishing, Zeist

Violovitsh NA (1974) A review of the Palaearctic species of the genus Chrysotoxum Mg. (Diptera, Syrphidae). Entomol Rev. 53:196-217

Wickramasinghe LP, Harris S, Jones G, Jennings NV (2004) Abundance and species richness of nocturnal insects on organic and conventional farms: Effects on agricultural intensification on bat foraging. Conserv Biol 18:1283-1292

Publisher's Note Springer Nature remains neutral with regard to jurisdictional claims in published maps and institutional affiliations. 